\title{
Farklı Çaplardaki Zıvanaların Kurşun İle Sabitlenmesinin Kayma Dayanımına Etkisi
}

\author{
Tülin Çelik $^{1^{*}}$, Şükran Tanrıverdi ${ }^{2}$ \\ 1* Aksaray Üniversitesi, Mühendislik Fakültesi, İnşaat Mühendisliği Bölümü, Aksaray, Türkiye, (ORCID: 0000-0001-8638-9579), tulinsandikci@gmail.com \\ ${ }^{2}$ Aksaray Üniversitesi, Mühendislik Fakültesi, İnşaat Mühendisliği Bölümü, Aksaray, Türkiye, (ORCID: 0000-0001-9751-5788), sukran_tugrulelci@hotmail.com
}

(2nd International Conference on Access to Recent Advances in Engineering and Digitalization (ARACONF)-10-12 March 2021)

(DOI: 10.31590 /ejosat.897808)

ATIF/REFERENCE: Çelik, T. \& Tanrıverdi, Ş. (2021). Farklı Çaplardaki Zıvanaların Kurşun İle Sabitlenmesinin Kayma Dayanımına Etkisi. Avrupa Bilim ve Teknoloji Dergisi, (24), 24-29.

$\ddot{O} \mathbf{z}$

Yapıldıkları dönemin ekonomik, sosyal ve kültürel özelliklerini yansıtan geçmişten günümüze kadar ulaşan yapılara yığma yapılar denir. Bu yapılar doğal afetler, doğa olayları, zeminden kaynaklı problemler ve insan etkileri gibi sebeplerden dolayı hasara uğramaktadır. Hasara uğrayan bazı yığma yapılar yıkılıp yeniden yapılırken, bazıları ise onarım ve güçlendirme gibi restorasyon çalışmaları ile ayakta tutulmaktadır. Bu yapılarda düşey doğrultudaki taşları birbirine bağlamada zıvana demirleri kullanılmıştır. Bu zıvana demirleri taş bloklar üzerine açılan yuvalara yerleştirildikten sonra kurşun ile sabitlenmiştir. Bu çalışmada farklı çaptaki zıvanaların kurşun ile sabitlenmesinin taş bloklar üzerindeki etkilerini araştırmak amacıyla 15 adet numune üzerinde kayma dayanım testleri gerçekleştirilmiştir. Deney sonuçları birbirleri ile karşılaştırılmıştır. Sonuçlar doğrultusunda günümüzde özellikle onarım ve güçlendirmede kullanılan zıvana demirlerinin kurşun ile sabitlenmesinin önemi ve zıvana demirlerinin çaplarının nasıl olması gerektiği konusunda önerilerde bulunulmuştur.

Anahtar Kelimeler: Zıvanalar, Kurşun, Geleneksel yapılar.

\section{The Effect on the Shear Strength of Dowels of Different Diameters Fixed with Lead}

\begin{abstract}
The structures that reflect the economic, social and cultural characteristics of the period they were built from the past to the present are called masonry structures. These structures are damaged due to reasons such as natural disasters, natural events, soil-based problems and human effects. While some damaged masonry structures are demolished and rebuilt, some are kept alive by restoration works such as repair and strengthening. Dowel irons were used to connect the vertical stones to each other in these structures. These dowel irons were placed in the holes opened on the stone blocks and then fixed with lead. In this study, shear strength tests were carried out on 15 samples in order to investigate the effects of lead fixation of dowels of different diameters on stone blocks. The experimental results have been compared with each other. In line with the results, suggestions were made on the importance of fixing the dowel irons with lead, especially used in repair and strengthening, and how the diameters of the dowel irons should be.
\end{abstract}

Keywords: Dowels, Lead, Masonry structures.

\footnotetext{
*Sorumlu Yazar: tulinsandikci@ggmail.com
} 


\section{Giriş}

Yığma yapılar, toplumun yaşam biçimlerini ve kültürlerini, yaşadıkları bölgelere yansıtmak için inşa ettikleri, kendilerine özgü yapılardan oluşmaktadır. $\mathrm{Bu}$ yapılar, toplum düzeyinde kabul edilen, korunup gelecek nesillere aktarılması gereken ve kültürel öğeleri yansıtan yapılardır. Yığma yapılar biçimsel ve işlevsel olarak esinlenilen bir yapı kültürü olması açısından oldukça önemlidir. Bu nedenle yı̆̆ma yapıların zaman içerisinde meydana gelen çevresel ve insan etkilerinden kaynaklanan hasarlara karşı korunması gerekmektedir. Yapılarda oluşan hasarların giderimesi için yapılacak olan onarım ve güçlendirme çalışmalarında, aslına uygun malzeme kullanımı ve yapıya müdahalenin en az seviyede tutulması oldukça önemlidir. $\mathrm{Bu}$ yapılarda en yaygın olan onarım ve güçlendirme çalışmalarından biride zıvana uygulamasıdır.

Zıvanalar, üst üste gelen taş blokları birbirine bağlayarak yapıya gelen yatay kuvvetlere karşı taş blokların hareketini engelleyen metal bağlantı elemanlarıdır. Taş blokları birbirine sabitlemek için kullanılan zıvana, alttaki ve üstteki taş bloklara açılan oyuklara yerleştirilir ve zıvananın çevresine kurşun dökülerek sabitlenir. Zıvanaların sabitlenmesi için dökülen kurşun malzemesi sayesinde, zıvanalar taş bloklardan sıyrılmadan yerinde sabit kalabilmektedir.

MÖ.6. yy Yunan mimarisinde önemli yapılarda demir kelepçe ve kelepçenin üzerine eritilmiş kurşun dökülerek taş blokları birbirine sabitlenmiştir. Ayrıca bu yapılarda taş blokları yerine mıhlamak için zıvana çivileri kullanılmıştır. Minos ve Myken uygarlıkları döneminde, yumuşak taşların sürtünmelerden zarar görmemesi için demir zıvana çivileri kullanılmıştır. Zıvana demirin paslanmaması, sürtünmenin önüne geçilmesi ve zıvananın sabit kalması amacıyla etrafı kurşun dökülerek doldurulmuştur (Çördük, 2006). Romalılar ve Grekler de sütun parçalarının ve başlıklarının birbirine bağlanmasında kenet ve demir miller (zıvana) kullanmışlardır. Erken Osmanlı mimarisinde kenet ve saplama (zıvana) şeklindeki kullanımı kısıtlı olmakla beraber, özellikle 16. yüzyıl sonrasında yığma yapılarda kenet ve zıvana önemli bir malzeme konumuna yükselmiştir (Kurugöl ve Küçük, 2015).

Yığma yapılarda en yaygın olarak görülen hasar türü kayma (kesme) kuvvetleri nedeniyle meydana gelen kesme çatlaklarıdır. $\mathrm{Bu}$ yapılarda deprem ve zemin etkilerinden kaynaklı oluşan kesme çatlakları yapıda ani göçmelere neden olmaktadır. Literatürde metal bağlantı elemanı olarak kullanılan zıvanalar ile ilgili çalışmaların oldukça az ve yetersiz olmakla birlikte zıvanaların yığma yapılar üzerinde olumlu etkilerinin olduğu görülmüştür.

Nikolić vd. (2019), çalışmasında taş yığma yapıları metal bağlantı elemanı olan dübel ve kenetleri ile güçlendirilmiştir. Taş yığma yapıların davranışlarının sayısal modeli oluşturmak için sonlu ayrık eleman yöntemi ile modellemiştir. Metal bağlantı elemanları olan kenet ve zıvanaların malzeme ve geometrik modelini geliştirmiş ve sonlu ayrık eleman modeli ile analizlerini gerçekleştirmiştir. Analiz sonuçlara göre, dinamik davranış incelendiğinde taş yığma yapılarda kullanılan metal bağlantı elemanlarının tarihi anıtların davranışlarının simülasyonunda uygulanan modelin performansını olumlu yönde etkilemiştir. Tarihi yapıların depreme karşı dayanıklılı̆̆ını arttırmada metal bağlantı elemanlarının olumlu etkileri olduğu görülmüştür. Soti ve Barbosa (2019), deneysel ve sayısal olarak donatısız yı̆̆ma duvarı ve güçlendirilmiş yığma duvarları modelleyerek çözümlemiş ve sonuçlarını birbiri ile kıyaslanmıştır. Elde edilen sonuçlara göre, çelik zıvanaların duvarların deformasyon kapasitesini iyileştirmede etkili olduğu görülmüştür. Simonović ve Simonović (2018), yığma duvarları iki farklı yaklaşım olan çelik 1zgara ve FRC dübelli betonarme paneller ile güçlendirerek analizleri yapmıştır ve sonuçları birbirleri ile kıyaslamıştır. Sonuç olarak güçlendirme için uygulanan sistemlerinin kalitesi üzerindeki en önemli etkinin yığma duvarın yeterli bir şekilde güçlendirilmesi gereken elemanların rijitlik seçimi ile ilgili olduğu görülmüştür. Ural vd. (2015), farklı kenet ve zıvana sistemlerine sahip yığma duvar modelleri üzerinde gerçekleştirilen deney sonuçlarına göre sistemlerin yığma duvarların kesme kapasitesini nasıl etkilediğini inceleyerek bu konu ile ilgili bazı önerilerde bulunmuştur. Demir (2012), çok tabakalı yığma duvarların kayma davranışına etkisini incelemiştir. Çalışmasında değişken olarak, eksenel gerilme düzeyi, kenet ve zıvana kullanımı ve dış tabakalar arasında iç moloz dolguyu ele almıştır. Sonuç olarak, kenetlerin kullanılması çatlak dağılımını etkilemekte ve kullanılan taşın çekme dayanımının nispeten düşük olması nedeniyle kenetlerin etkinliklerinin sınırlandığından bahsetmiştir.

$\mathrm{Bu}$ çalışma kapsamında, taş bloklar üzerine farklı çaplardaki zıvanalar kurşun yardımı ile sabitlenmiştir. Farklı çaplara sahip deney numuneleri üzerinde kayma dayanım testleri yapılmıştır. Zıvana demirinde kullanılması gereken optimum çap incelenerek ve kurşunun öneminden bahsedilmiştir.

\section{Materyal ve Metot}

\subsection{Yığma Taşların Basınç Dayanımı}

Deneysel çalışmada 200x300x600 mm³ ebatlarında volkanik kökenli tüf taşı kullanılmıştır. Aksaray Üniversitesi Mühendislik Fakültesi İnşaat Mühendisliği Bölümü Yap1 Mekaniği Laboratuarında volkanik tüf taşı için basınç dayanım testleri ve üç noktada eğilme çekme dayanımı testleri yapılmıştır. Taşın basınç dayanım testi, TS EN 772-1+A1 (2015)'de belirtildiği şekilde 6

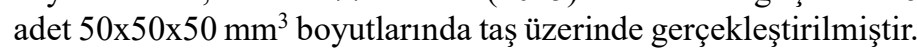
Basınç dayanım testi sonucunda taşın ortalama basınç dayanımı 4,13 $\mathrm{MPa}$ olarak hesaplanmıştır. Taşın basınç dayanımı $(\sigma)$, deneyde elde edilen kırılma yükünün $(\mathrm{N})$ uygulanan alana $(\mathrm{A})$ bölünmesiyle elde edilmiştir. Tablo 1'de taşın basınç dayanım sonuçları verilmiştir.

Tablo 1. Taşın basınç dayanım test sonuçları

\begin{tabular}{|c|c|c|c|c|}
\hline \multirow[t]{2}{*}{ Numune No } & \multicolumn{2}{|c|}{$\begin{array}{c}\text { Enkesit } \\
\text { boyutları } \\
(\mathrm{mm})\end{array}$} & \multirow[t]{2}{*}{$\begin{array}{l}\text { Kırılma } \\
\text { Yükü (N) }\end{array}$} & \multirow[t]{2}{*}{$\begin{array}{c}\text { Basınç } \\
\text { Dayanımı } \\
\text { (Mpa) }\end{array}$} \\
\hline & $\mathrm{a}$ & $\mathrm{b}$ & & \\
\hline A1 & 50 & 50 & 12650 & 5,06 \\
\hline $\mathrm{A} 2$ & 50 & 50 & 10850 & 4,34 \\
\hline A3 & 50 & 50 & 8570 & 3,43 \\
\hline A4 & 50 & 50 & 9970 & 3,98 \\
\hline A5 & 50 & 50 & 11450 & 4,58 \\
\hline \multirow[t]{3}{*}{ A6 } & 50 & 50 & 8450 & 3,38 \\
\hline & & & Ortalama & 4,13 \\
\hline & & & dart Sapma & 0,66 \\
\hline
\end{tabular}


Deneyde kullanılan taşın eğilmede çekme dayanımını belirleyebilmek amaciyla TS EN 772-6 (2004) standartı

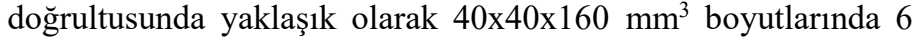
adet taş üzerinde üç noktada eğilme testleri yapılmıștır. Yapılan test sonuçları Tablo 2'de verilmiștir. Taşın ortalama çekme dayanımı 0,71 $\mathrm{MPa}$ elde edilmiştir. Taşın eğilmede çekme dayanımı Denklem 1 ile hesaplanmıştır.

$\mathrm{R}_{\mathrm{tf}}=\frac{P L}{b d^{2}}$

Formülde $\mathrm{R}_{\mathrm{tf}}$ : Eğilmede çekme dayanımı, P: taşın kırılma yükü, L: mesnet silindirlerinin arasındaki uzaklık, b: taşın genişliği, d taşın yüksekliğidir.

Tablo 2. Taşın üç noktada ĕgilme test sonuçları

\begin{tabular}{ccc}
\hline Numune No & $\begin{array}{c}\text { Kırılma Yükü } \\
(\mathrm{N})\end{array}$ & $\begin{array}{c}\text { Ĕgilmede } \\
\text { Çekme } \\
\text { Dayanımı } \\
\text { (Mpa) }\end{array}$ \\
\hline A1 & 490 & 0,77 \\
A2 & 490 & 0,62 \\
A3 & 560 & 0,88 \\
A4 & 500 & 0,68 \\
A5 & 450 & 0,59 \\
A6 & 570 & 0,72 \\
\hline & Ortalama & 0,71 \\
\hline
\end{tabular}

Çalışmada kullanılan farklı çaptaki zıvanaların çekme dayanımlarını belirlemek amacıyla çekme testleri yapılmıştır. $\mathrm{Bu}$ testler TS EN ISO 6892-1 (2020) (Metalik Malzemeler Çekme Deneyi) standartı baz alınarak yapılmıştır. Zıvanaların çekme testleri sonucunda çekme dayanımları $290 \mathrm{MPa}$ olarak elde edilmiştir. Çekme dayanımı Denklem 2 ile hesaplanmıştır.

$\mathrm{R}_{\mathrm{m}}=\mathrm{F}_{\mathrm{m}}$

Denklemde kullanılan $\mathrm{R}_{\mathrm{m}}$ Z Zıvanaların çekme dayanımı, $\mathrm{F}_{\mathrm{m}}$ ise deney sırasında akmanın gerçekleşmesi sonucunda zıvananın dayandığg1 en büyük yüktür.

\subsection{Deneysel Çalışma}

$\mathrm{Bu}$ çalışmada çapları değişken olarak ele alınan ( $8 \mathrm{~mm}, 10$ $\mathrm{mm}, 12 \mathrm{~mm}, 14 \mathrm{~mm}, 16 \mathrm{~mm})$ zıvanaların taş bloklar üzerindeki etkilerini araştırmak amaciyla her bir numuneden 3 'er adet toplamda 15 adet numune üzerinde kayma testleri yapılmıştır. Deneysel çalışmada zıvana demirlerini temsilen sonsuz dişliler kullanılmıştır. Şekil 1'de deneyde kullanılan zıvanaların (sonsuz dişlilerin) çapları ve taş bloğun boyutları verilmiştir.

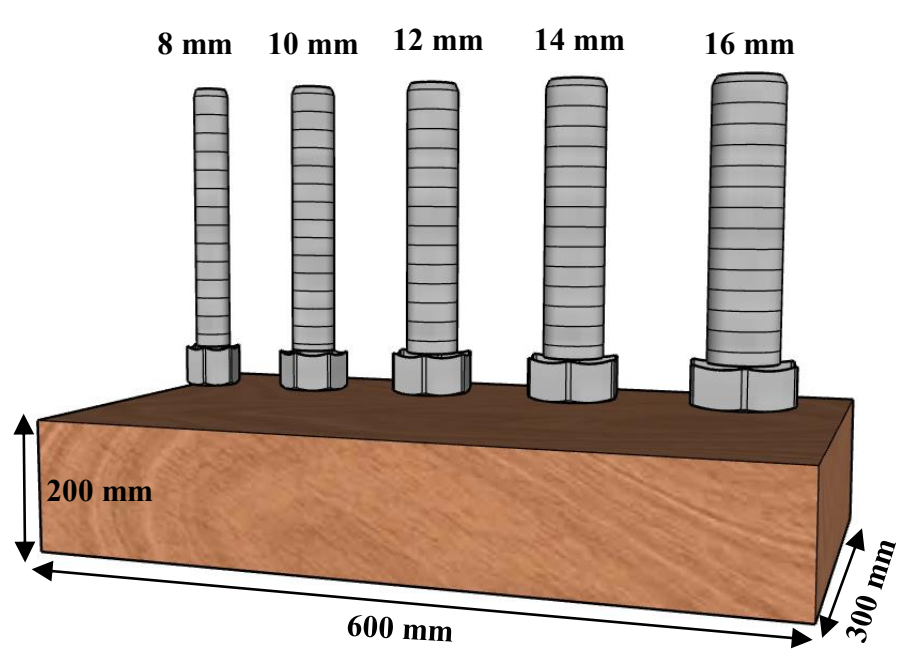

Şekil 1. Zıvanaların çapları ve taş bloğun boyutları

Çalışmaya başlamadan önce taş bloklar üzerine zıvana çaplarından büyük boşluklar açılmıştır. Bu boşluklara zıvana demirleri yerleştirilip zıvana yuvaları eritilen kurşun malzemesi ile Şekil 2'de gösterildiği gibi doldurularak deneye hazır hale getirilmiştir.
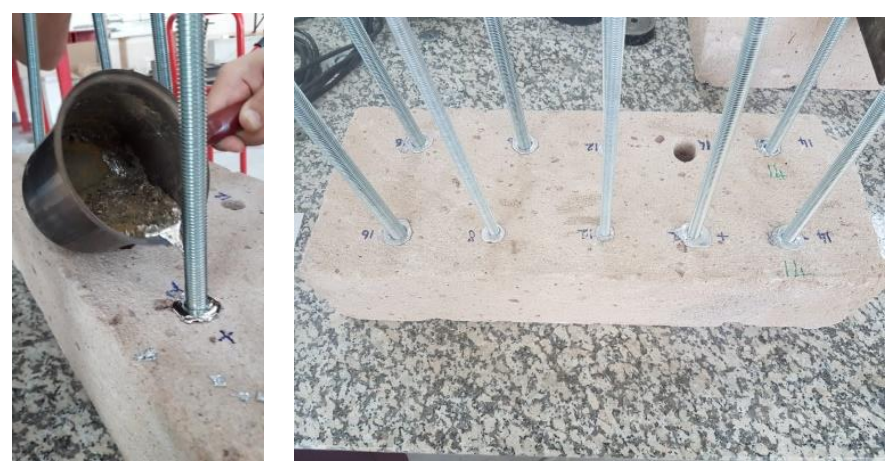

\section{Şekil 2. Zıvanaların kurşun ile doldurulması}

Deney numuneleri Şekil 3'de gösterildiği gibi deney düzeneğine yerleştirilmiştir. Deney numunelerinin üzerine hidrolik pompayı yerleştirmek amacıyla dikdörtgen kesitli plakalar yerleştirilmiştir. Bu plakaların üzerine hidrolik pompa ve hidrolik pompanın üzerine de 50 ton kapasiteye sahip yük hücresi konulmuştur. Kayma testinde zıvanalar hidrolik pompa yardımıyla yukarıya doğru çekilmektedir. Deney sırasında elde edilen kayma yükleri, hidrolik pompa üzerine yerleştirilen yük hücreleri aracılığıyla bilgisayar ortamına aktarılmasıyla elde edilmiştir. 


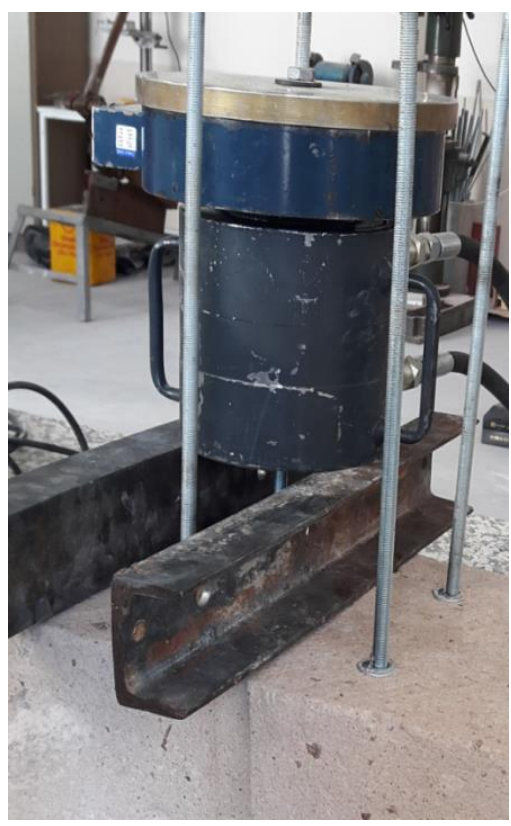

Şekil 3. Deney düzeneğ $i$

\section{Araştırma Sonuçları ve Tartışma}

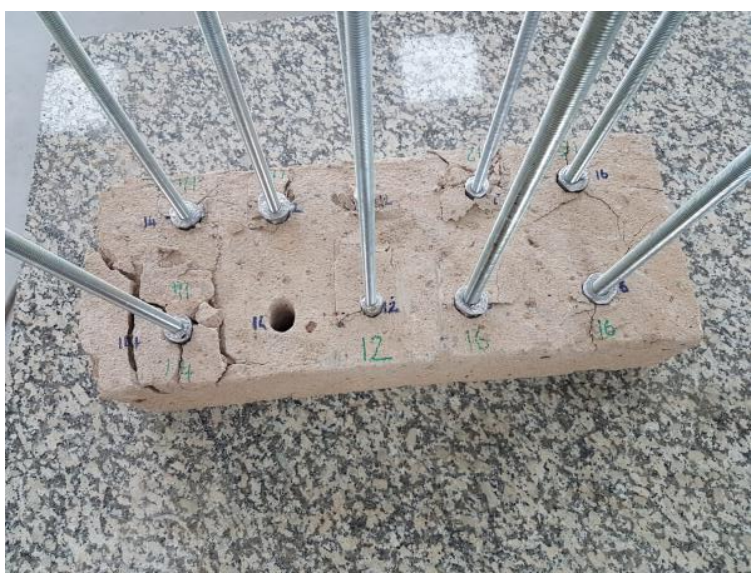

Şekil 4. Deney sonucunda taş bloklarda meydana gelen deformasyonlar

Farklı çaplara sahip zıvanaların, taş bloklar üzerine kurşun yardımıyla sabitlenerek kayma dayanım testleri yapılmıştır. Deney sonucunda taş blok üzerinde meydana gelen deformasyonlar Şekil 4'de gösterilmiştir.
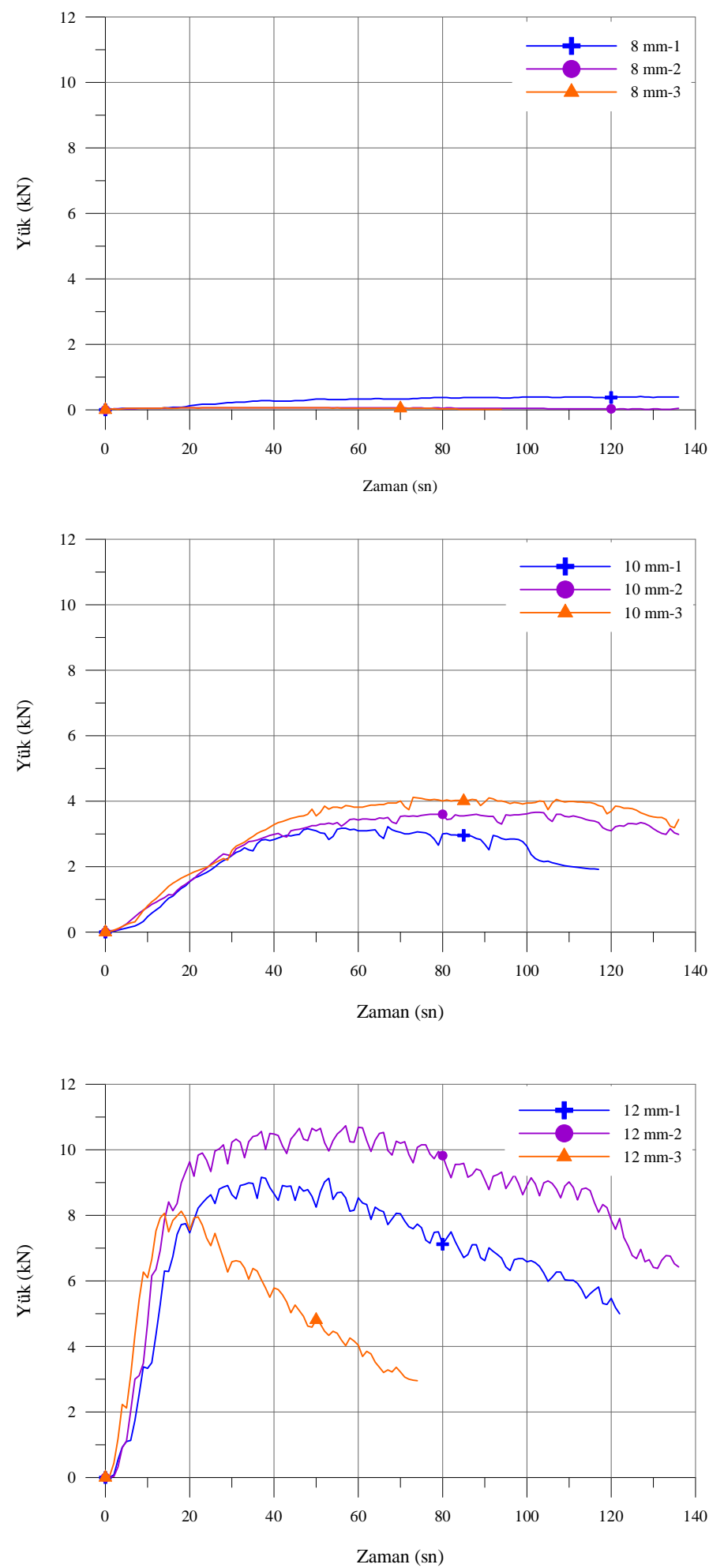

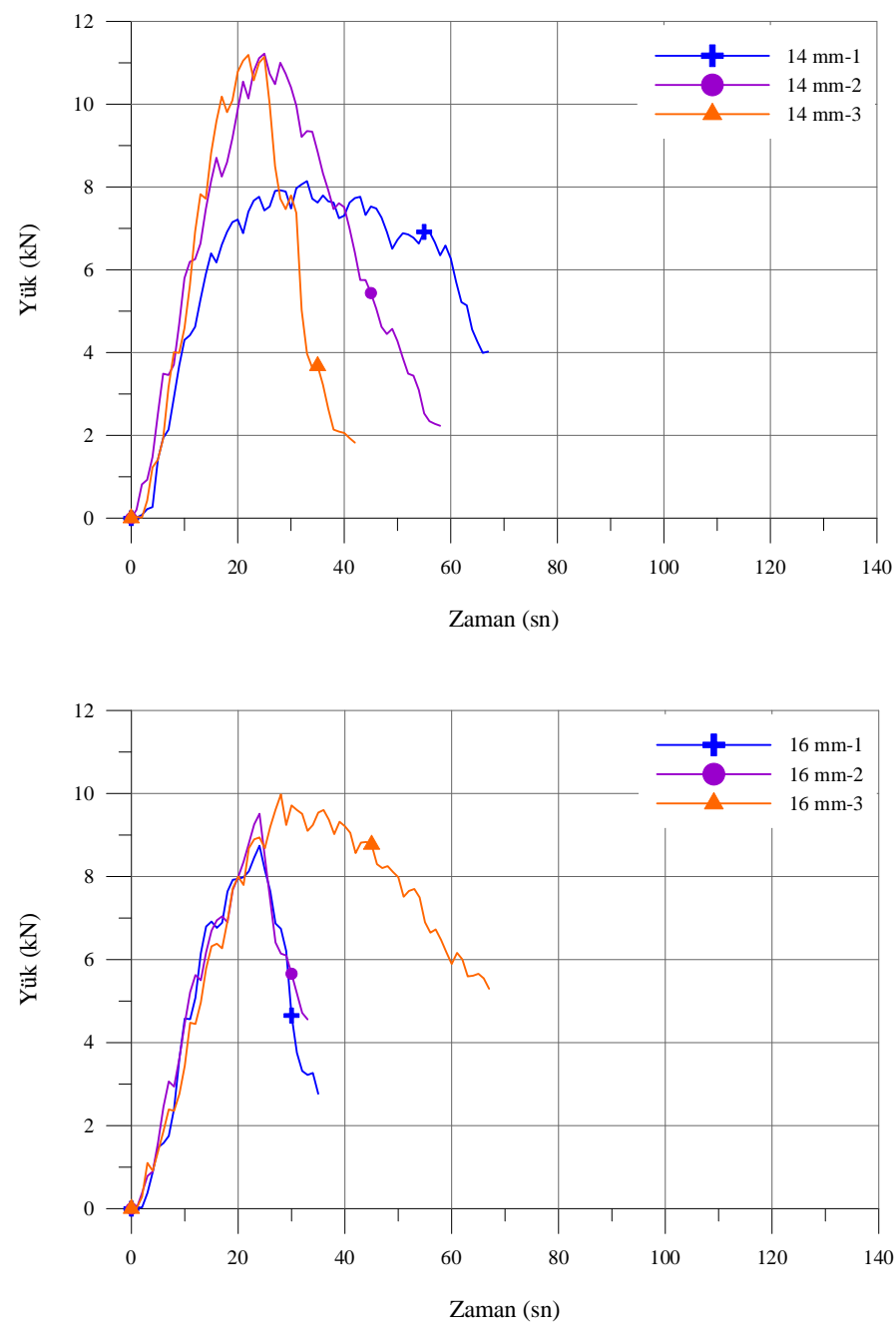

\section{Şekil 5. Deney numunelerinin yük-zaman grafikleri}

Şekil 5'de deney numunelerinin yük-zaman grafikleri verilmiştir. Grafikler incelendiği zaman $8 \mathrm{~mm}$ çapına sahip zıvanalar ile yapılan deney numuneleri birbirine yakın davranışlar sergilemiştir. Deney numuneleri arasında en az yükü taşıyan deney numunesi $8 \mathrm{~mm}$ çapına sahip zıvana ile yapılan numune olmuştur. $8 \mathrm{~mm}$ zıvana çaplı deney numunesi sırası ile maksimum $0,4 \mathrm{kN} 0,06 \mathrm{kN}$ ve $0,07 \mathrm{kN}$ yük taşımışlardır. $\mathrm{Bu}$ deney numunelerinde zıvanalarda sıyrılmalar meydana gelmiştir. $\mathrm{Bu}$ sebeple fazla yük taşıyamamışlardır.

10 mm çapına sahip zıvanalı numunelerin taşıdıkları yükler birbirlerine oldukça yakındır. $10 \mathrm{~mm}$ çaplı zıvana deneylerinde birinci deney $3,22 \mathrm{kN}$, ikinci deney $3,66 \mathrm{kN}$, üçüncü deney ise $4,11 \mathrm{kN}$ yük taşımışlardır. $\mathrm{Bu}$ deney numuneleri $8 \mathrm{~mm}$ çapına sahip deney numunelerine göre daha fazla yük taşıyıp daha sünek davranış sergilemiştir.

Diğer bir deney numunesi olan $12 \mathrm{~mm}$ çapa sahip zıvanalarla yapılan deney numuneleride, diğer deney numunelerinde olduğu gibi taşıdıkları yük ve davranış bakımından birbirlerine oldukça yakındır. Şekil 5 'te verilen yük-zaman grafinde de görüldüğü gibi $12 \mathrm{~mm}$ çaplı deney numunelerinden 1 . deney numunesi $9,16 \mathrm{kN}$, 2 . deney numunesi $10,73 \mathrm{kN}$ ve 3 . deney numunesi $8,12 \mathrm{kN}$ yük taşımışlardır. Zıvana çapı arttıkça deney numunelerinin taşıdıkları yüklerde artmıştır. $8 \mathrm{~mm}$ çapına sahip deney numunelerinde olduğu gibi sıyrılmalar gözlemlenmemiştir.
Zıvana çapı 14 mm olan deney numuneleriyle yapılan kayma testleri sonucunda üç deney numunesinin taşıdıkları maksimum yük sırası ile $8,14 \mathrm{kN}, 11,22 \mathrm{kN}$ ve 11,19 kN'dur. Deney sonucunda en fazla yükü taşıyan deney numunesi $14 \mathrm{~mm}$ çapına sahip zıvanalarla yapılan deney numuneleri olmuştur.

$16 \mathrm{~mm}$ çaplı zıvanalarla diğer numunelerde olduğu gibi üç adet numune üzerinde deney işlemi gerçekleştirilmiştir. Deney sonucunda deney 1 numunesi maksimum 8,74 kN, deney 2 numunesi 9,51 kN yük taşırken deney 3 numunesi ise $9,97 \mathrm{kN}$ yük taşımıştır. $16 \mathrm{~mm}$ çapına sahip deney numunesi $14 \mathrm{~mm}$ çaplı zıvana ile yapılan deney numunesine göre daha az yük taşımıştır.

\section{Sonuç}

Bu çalışmada farklı çaptaki zınavaların kurşun ile taş bloklara sabitlenmesinin kayma dayanımlarına etkisi test edilmiştir. Deneysel olarak incelenen bu çalışmada $8 \mathrm{~mm}, 10 \mathrm{~mm}, 12 \mathrm{~mm}$, $14 \mathrm{~mm}$ ve $16 \mathrm{~mm}$ çaplarına sahip zıvanalar taş bloklara açılan boşluklara kurşun yardımıyla sabitlenmiştir. Her bir numuneden 3 'er adet yapilarak toplamda 15 adet numune üzerinde kayma testleri yapılmıştır. Deneysel çalışılan numunelerin ortalama yükzaman grafikleri Şekil 6'da zıvana çaplarına karşılık gelen ortalama yüklerde Şekil 7'de verilmiştir.

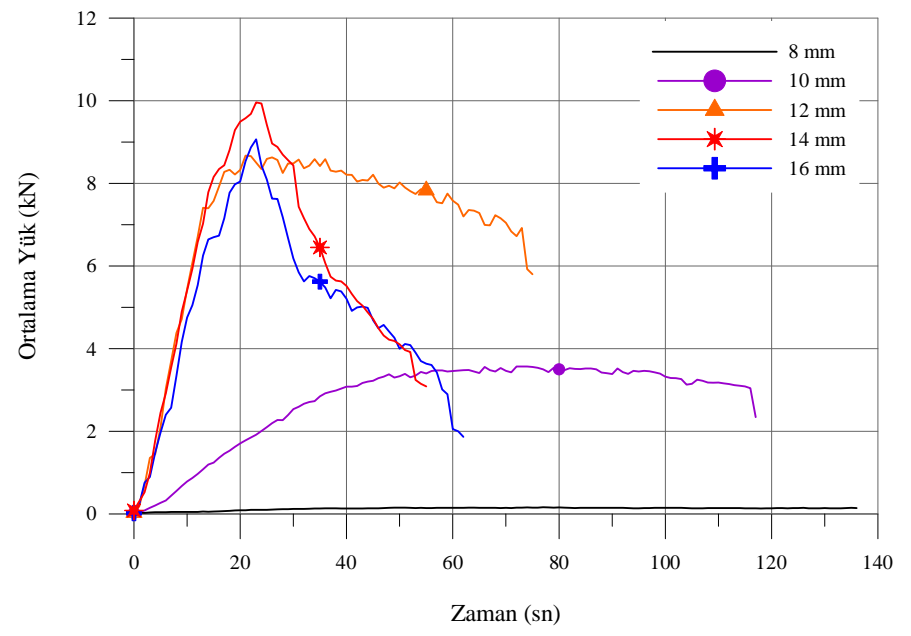

Şekil 6. Deney numunelerinin ortalama yük-zaman grafikleri

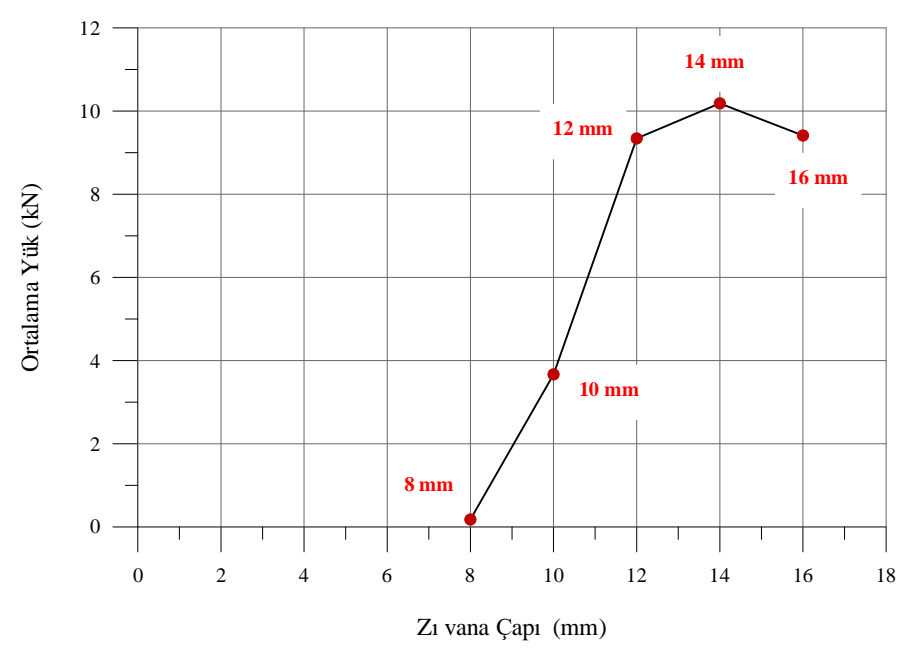

Şekil 7. Deney numunelerinin ortalama yük-zıvana çapı grafiği 
- Deney sonucunda elde edilen grafiklerde görüldüğ̈̈ gibi en az yükü taşıyan $8 \mathrm{~mm}$ çaplı zıvana ile yapılan deney numunesi olmuştur. Deney sırasında bu numunelerde zivanalar taş bloklar üzerinden sıyrılmıştır. $8 \mathrm{~mm}$ çaplı zıvanalı deney numuneleri deney sonucunda ortalama maksimum $0,17 \mathrm{kN}$ yük taşımıştır.

- Çap miktarı $10 \mathrm{~mm}$ olan deney numunelerinde 8 mm'ye göre yük taşıma kapasitelerinde artış meydana gelmiştir. $8 \mathrm{~mm}$ 'lik deney numunelerine göre daha sünek bir davranış sergilemiştir. $10 \mathrm{~mm}$ çaplı deney numunelerinin ortalama maksimum yük değeri 3,66 kN'dur.

- Deney sonucu grafikler incelendiği zaman $12 \mathrm{~mm}$ çapına sahip zıvana ile yapılan deney numunelerinin taşıdığ 1 ortalama maksimum yük değeri, $10 \mathrm{~mm}$ ve $8 \mathrm{~mm}$ çapına sahip zıvanalarla yapılan deney numunelerine göre daha fazladır. $12 \mathrm{~mm}$ çaplı deney numuneleri ortalama $9,34 \mathrm{kN}$ maksimum yük taşımıştır.

- Çap1 $14 \mathrm{~mm}$ olan zıvanalarla yapılan deney numuneleri diğer bütün deney numunelerine göre daha fazla yük taşımıştır. Bu deney numunelerinin taşıdığı ortalama maksimum yük $10,18 \mathrm{kN}$ değerindedir. Yapılan deneysel çalışma sonuçlarına bakıldığında zıvana çapı arttıkça yük değeride artmiştır.

- Zıvana çapı $16 \mathrm{~mm}$ olan en büyük çaplı deney numunelerinde taşıdıkları yüklerde azalma gözlemlenmiştir. $14 \mathrm{~mm}$ çapına sahip deney numuneleri ile karşılaştırıldığında bu numunelere göre ortalama daha az yük taşımıştır. Deney sonucunda $16 \mathrm{~mm}$ çapına sahip zıvanalarla yapılan deney numunelerinin taşıdığ yük değeri 9,41 kN'dur.

- Z Zıvana çapı daha da arttıkça deney numunelerinin taşıdıkları maksimum yükün daha da azalacağı yapılan deney sonuçlarına göre öngörülmektedir. deney sonucunda elde edilen veriler doğrultusunda optimum zıvana çap1 $14 \mathrm{~mm}$ olarak belirlenmiştir.

- Zıvanaların sabitlenmesi için kullanılan kurşunun yapılan deney sonuçlarına göre büyük ölçüde zıvananın taş bloklardan sıyrılmasını engellediği görülmüştür.

\section{Kaynakça}

Çördük, A. (2006). Yunan ve Roma mimarisindeki yap1 teknikleri. Izmir: Ege Üniversitesi, Sosyal Bilimler Enstitüsü,(Yüksek Lisans Tezi).

Demir, C. (2012). Seismic behaviour of historical stone masonry multi-leaf walls (Doctoral dissertation, $\mathrm{PhD}$ Dissertation. Turkey: Istanbul Technical University (ITU).

Kurugöl, S., \& Küçük, A. G. S. G. (2015). Tarihi Eserlerde Demir Malzeme Kullanım ve Uygulama Teknikleri. Tarihi Eserlerin Korunması ve Geleceğe Güvenle Devredilmesi Sempozyumu Bildiri Kitabl, Ístanbul, 521-536.

Nikolić, Ž., Smoljanović, H., \& Živaljić, N. Analysis of metal connector's effect on seismic resistance of dry stone masonry structures. Computational Methods in Structural Dynamics and Earthquake Engineering.

Simonović, V., \& Simonović, G. (2018, June). Numerical Investigation of Possible Strengthening of Masonry Walls. In International Symposium on Innovative and Interdisciplinary Applications of Advanced Technologies (pp. 175-181). Springer, Cham.

Soti, R., \& Barbosa, A. R. (2019). Experimental and applied element modeling of masonry walls retrofitted with near surface mounted (NSM) reinforcing steel bars. Bulletin of Earthquake Engineering, 17(7), 4081-4114.

Ural, A., Kara, M. E., \& Uslu, S. (2015). Kenet ve Zıvanaların Yığma Duvarların Kesme (Kayma) Davranışına Etkisi, 5. Tarihi Eserlerin Güçlendirilmesi ve Geleceğe Güvenle Devredilmesi Sempozyumu, 537-548.

TS EN 772-1+A1. (20159. Kagir birimler-deney yöntemleribölüm 1: Basınç dayanımının tayini, Türk Standartları Enstitüsü, Ankara.

TS EN 772-6. (2004). Kagir birimler-deney metotları-bölüm 6: Beton kagir birimlerin eğilmede çekme dayanımının tayini, Türk Standartları Enstitüsü, Ankara.

TS EN ISO 6892-1. (2020). Metalik malzemeler-çekme deneyibölüm 1: Ortam sıcaklığında deney metodu, Türk Standartları Enstitüsü, Ankara. 